\title{
Tarekat Da'wah through the Islamic Educational Institutions at Pesantren Suryalaya
}

\author{
Jujun Junaedi \\ Universitas Islam Negeri Sunan Gunung Djati Bandung, Indonesia \\ *email.jujun.junaedi@uinsgd.ac.id
}

\begin{abstract}
This study seeks to analyze the objectives and methods of da'wah tarekat through Islamic educational institutions at pesantren Suryalaya. The research was conducted by exploring the basic concepts, objectives, principles, ethics, and tarekat-based education methods applied in Islamic education institutions MTs-MA Serbia Bakti. This research uses a qualitative approach with descriptive-analytic methods. The data were collected through observation, interviews, and literature studies, while data analysis was carried out through phenomenological reduction, eidetic reduction, and transcendental reduction. The study results concluded that the basic concepts, principles, and ethics of tarekat da'wab applied in Islamic educational institutions were based on the teachings of TQN, Tanbih manuscripts, Pearl strands, and the exemplary figure of Abah Anom. The tarekat da'wah aims to form buman beings who are Cageur-Bageur and Serba-Bakti. This goal is implemented into the vision, mission, and profile of the institution's graduates. Drikir becomes the epicenter of the tarekat da'wah method as an effort of Tarkiyat al-Nafs. The research implication shows that the commitment and consistency of the teachings of TQN Suryalaya to form a perfect buman (insan kamil) in various spheres of life
\end{abstract}

Keywords : Tarekat da'wah; cageur-bageur; serba-bakti; dziler; Islamic education.

\begin{abstract}
ABSTRAK
Penelitian ini berupaya untuk menganalisis tujuan dan metode dakwah tarekat melalui lembaga pendidikan Islam di Pesantren Suryalaya. Penelitian dilakukan dengan menggali konsep dasar, tujuan, prinsip, etika dan metode pendidikan berbasis tarekat yang diterapkan di lembaga pendidikan Islam MTs-MA Serba Bakti. Penelitian menggunakan pendekatan kualitatif dengan metode deskriptif-analitik. Pengumpulan data dilakukan melalui observasi, wawancara dan studi pustaka, sedangkan analisis data dilakukan melalui reduksi fenomenologis, reduksi eiditis dan reduksi transcendental. Hasil penelitian menyimpulkan bahwa konsep dasar, prinsip dan etika dakwah tarekat yang diterapkan di lembaga pendidikan Islam bersumberkan pada ajaran TQN, naskah Tanbih, Untaian Mutiara dan keteladanan dari sosok Abah Anom. Tujuan dakwah tarekat adalah membentuk manusia yang Cageur-Bageur dan Serba Bakti. Tujuan ini dimplementasikan ke dalam visi, misi dan profil lulusan lembaga. Dzikir menjadi episentrum metode dakwah tarekat sebagai upaya Tazkiyat al-Nafs yang pada prakteknya dilakukan untuk mengoreksi tindakan agar tilik pamilih dina nyiar jalan kahadean labir batin, dunia akbirat, sangkean ngeunah nyawa betah jasad, memperhatikan tindakan dan niat tindakan agar sesuai dengan kebaikan sehingga mencapai kebahagiaan lahir batin, dunia dan akhirat. Implikasi penelitian menunjukkan bahwa komitmen dan konsistensi ajaran TQN Suryalaya dalam upaya membentuk manusia sempurna (insan kamil) dalam berbagai ruang lingkup kehidupan.
\end{abstract}

Kata kunci : Dakwah tarekat; cageur-bageur; serba-bakti; dzikir; pendidikan Islam.

Received: Agustus 2020. Accepted: Oktober 2020. Published: Desember 2020. 


\section{INTRODUCTION}

Islamic boarding school education is a traditional Islamic educational institution aims to understand, appreciate, and practice Islam's teachings (tafaqquh fiddin) by emphasizing the importance of Islamic morals as a guide for everyday social life (Mastuhu, 1994: 6). Pesantren (Islamic boarding school) is considered to be the first educational institutions in the Indonesian Islamic world which continue to evolve from the form of a boarding house to a form of a class system, such as schools in the European system, with the name madrasah (Steenbrink, 1986: 21; Azra, 1999: 104).

In Java, pesantren education system was initially seen as a form of combination between madrasah and tarekat activity center (Zamakhsary, 1983: 34). In this case, the madrasab is an educational institution that provides the teaching of sciences related to Islamic teachings such as reading and writing the Qur'an, hadith, fiqh, and others. Moreover, the tarekat is related to the system of behavioral or moral improvement. Thus, the combination of the two strengthens the orientation of education in Islam in shaping the generation of tafaqqub fiddin.

This combined madrasah and tarekat system are still being implemented in several pesantren in Java. However, many pesantren have evolved only into madrasah, integrated Islamic schools, and/or turned into modern pesantren by incorporating general science and technology as other skills. The existence of pesantren coincided with the struggle of Muslims in Indonesia in expelling the invaders. Pesantren appears as an Islamic educational institution capable of providing teaching in the form of strengthening mentality, leadership, ways of thinking, staying power, and strengthening the community's social awareness. In this case, pesantren carry out religious, educational, social, and cultural functions. These four functions are carried out in order to strengthen the Islamic spirit of Indonesian Muslims.

The development of pesantren, which evolved by combining the school education system, can be used as an alternative in addressing educational problems in the era of globalization (Muhaimin, 2009: 102). Pesantren have become cultural and religious strongholds with strong values, principles, and strength amidst various scientific developments and technological sophistication (Azra, 1999). This is mainly related to dehumanization as a sociological implication in the series of human life. 
This dehumanization can be seen from several life indicators that reflect the fading of human care, solidarity, and sensitivity to others. Changes in social interaction structure as an implication of technology direct humans to become solitary, loners, and even selfish. In this case, technological sophistication changes human interaction patterns from being face-to-face to media (Rustandi, 2019: 88).

The uniqueness of pesantren education emphasizes the development of Muslim personalities based on the moral values of Islamic teachings. Humanitarian crises (dehumanization) in the form of loss of human identity, loss a concern, rampant humanitarian discrimination, crime problems, degradation of morality, low ethical values, and so on are humanitarian challenges that must be resolved. In this case, pesantren education system is oriented not only to develop cognition but also to improve the mentality, personality, and values of human morality based on Islamic teachings.

The era of globalization raises various technological threats in the field of education. This is related to the basic values of human morality, which beginning to fade in social life. For example, the magnitude of information anomalies is due to the spread of hoaxes, hate speech and negative content propaganda, unwise use of mass media, high digital crime in cybercrime, cyberbullying, pornography, porno-action, and so on. Some of these technological threats become sociological problems that affect patterns of human interaction. Therefore, Islamic education institutions such as pesantren that focus on cultivating a mentality and moral personality are an alternative in responding to these threats. Pesantren is a space for the actualization of Islamic da'wah, which plays the role and function of religion, education, society, and culture.

One of pesantren that combines the madrasah and tarekat education systems is pesantren Suryalaya in Tasikmalaya. Pesantren Suryalaya is one of pesantren that maintains the orientation of the madrasab and Sufism activities or tarekat as the core of public education. Since 1963, pesantren Suryalaya has established a multi-purpose educational institution that develops formal education such as Madrasah Tsanawiyyah, Madrasah Aliyah, Junior High Schools, Senior High Schools, and Universities. Islamic education institutions' existence in the form of pesantren and other formal educational institutions in Suryalaya is an actualization of the tarekat da'wah activities in carrying out three functions: ta'lim, tarbiyah, and social. These three da'wah functions of the Suryalaya tarekat are intended to transform science and 
language within a scientific framework, so that sufistic activity can become an alternative in responding to the threat of globalization (Usman, 2017: 180). Therefore, the Islamic education-based tarekat da'wah model at pesantren Suryalaya can be seen to transform the values of Islamic teachings (tasawuf) in the personality and activities of human life.

In the context of da'wah, tarekat-based Islamic education seeks to transmit messages of Islamic teachings based on human nature. Da'wah is an effort to invite people to the path of Allah SWT. At the same time, tarekat is closely related to forming the Muslim personality based on the crystallization of the values of monotheism in human behavior. Da'wah based on tarekat is oriented towards a da'wah approach with a humanist model and pattern of spreading Islamic messages, relying on the potential for goodness embedded in humans (Qomariah, 2019: 184). The development of a model of tarekat da'wah activities to become an alternative to Islamic education can answer the spiritual barriers of modern society. He stated that the practice of talqin drikir in the tarekat congregation's activities is one of the efforts or methods of da'wah in strengthening the values of monotheism. Talqin dikikir can touch emotionalspiritual aspects (al-athify), rational aspects (al-aqliy), and sensory aspects (alhissiy) (Lutfhi, 2017: 378).

Moreover, the role and function of the talqin guardian in preaching the tarekat is important as a $d a^{\prime} i$ who directs $m a d^{\prime} u$ in the internalization of Islamic teachings. Talqin guardians as $d a^{\prime} i$ strengthen the implementation of da'wah with the dqikir method to strengthen efforts to develop da'wah in the era of globalization. In this case, talqin guardian is positioned as a $d a^{\prime} i$ with a function as mursyid who helps mad'u practicing the tarekat to form a mad'u personality according to Islamic moral values (Jamaludin, 2018): 174). Da'wah activities of the tarekat through Islamic education institutions implement the values of Sufistic education within the framework of open space actualization. In this case, pesantren Suryalaya's existence as a model for the da'wah of the tarekat is functioned not only for the ikhwan or congregation but also for all groups oriented towards improving personality and morals (Sayyi, 2017: 15-18). This Sufistic education's values serve as a frame of reference in developing models, patterns, methods, media, and the practice of da'wah activities in public education spaces.

The da'wah activities of the tarekat at the Islamic education institution, pesantren Suryalaya, can be found in several special activities. For example, students or santri are required to perform wirid, visit Abah Sepuh, 
and are also told about the sheik's management. Moreover, they are introduced to several tarekat traditions (in this case the Naqsabandiyah Qadiriyah Tarekat). Some activities of this tarekat are mandatory programs carried out to form the identity of students who are oriented towards spiritual awareness.

Several studies on tarekat da'wah models in various scopes of study have been carried out before. For example, Suherdiana's (2009) research explores the da'wah model of the fardiyah tarekat qadiriyah naqsabandiyah. It can be concluded that the preaching of fardiyah in tarekat activities is reflected through the pattern of relationships between mursyid as da'i and congregations or ikhwan as mad'u. The relationship between the two is oriented towards the formation of collective consciousness. Aripudin's research (2011) analyzes tarekat and da'wah's development in Indonesia. This research concludes that the historical roots of the tarekat are oriented towards the development of Islamic da'wah. Moreover, tarekat develops according to local styles so that it becomes a medium in transmitting Islamic teachings.

Other research was conducted by Salahudin (2013), who examined the communication patterns of the qadiriyah and naqsabandiyab tarekat groups. It is concluded that the communication events in the tarekat activities reflect the esoteric rite pattern to achieve self-quality, which has good character. The communication pattern of the tarekat relies on mursyid figure and is integrated with the values of Sufistic teachings in the practice of the tarekat. The communication process of the tarekat is represented through various symbols and interpretations of the symbols that take place and affect mursyid and ikhwan. Pujiastuti's research (2016) looks at the development of the qadiriyah and naqsabandiyah tarekat at Pesantren Suryalaya. It was concluded that the development of this tarekat was based on the figurative commitment of Abab Sepub and Abah Anom. Moreover, the four main practices of this tarekat include wiridan, manaqiban, khataman and talqin.

This research was developed by Sayyi (2017), which focuses on the testament of Sufistic education in the manuscript tanbih murshid tarekat qadiriyah wa naqsabandiyah. The study results concluded that the values of Sufistic education in the tanbih manuscript were oriented towards the formation of ikhwan identities who had a noble human degree (insan kamil). Moreover, this educational value is mandated to maintain humanity's noble values that appreciate, respect, and cherish. Another research was 
conducted by Qomariah (2019) regarding the da'wah of humanist tarekat. It is concluded that the tarekat da'wah approach is oriented towards the formation of a noble human personality through the implementation of tarekat practices based on the values of Islamic teachings. This humanist da'wah is carried out at the individual level and the community level in the congregation.

Meanwhile, research related to educational aspects in tarekat da'wah activities is more focused on using tarekat methods in the process of overcoming or rehabilitating drugs. For example, research conducted by Lestari (2013) on methods of therapy and rehabilitation for drug victims at pesantren Suryalaya; research by Mukri, Rosyadi and Saefuddin (2015) regarding methods of Islamic education in tackling drug abuse for adolescents in the Inabah Suryalaya adolescent cottage; Asror, Kusnawan and Fajar's (2017) research on the rehabilitation of victims of drug abuse through religious therapy at the Multipurpose Foundation Pondok Pesantren Inabah Suryalaya Garut; and research by Hudan Alfariz and Taftazani (2020) which measures the level of stress on drug abuse while undergoing rehabilitation at pesantren Suryalaya Tasikmalaya. The research focuses more on the role and function of pesantren Suryalaya Tasikmalaya with the tarekat method in rehabilitating drug victims.

Referring to some previous research, this study seeks to analyze the tarekat da'wah model through Islamic education institutions at pesantren Suryalaya. The research is more directed at exploring the aims and methods of da'wah through tarekat-based education as a model for the da'wah activities of the tarekat in Suryalaya. In other words, this research seeks to explore the objectives, patterns, processes and methods of da'wah through tarekat-based education as an integral part of the implementation of Islamic da'wah. The object of this research is Madrasab Tsanawiyah and Madrasah Aliyah Serba Bakti Pesantren Suryalaya Tasikmalaya. These two institutions were chosen as research objects because both MTs and MA Serba Bakti are formal educational institutions under pesantren Suryalaya that combine the madrasah and tarekat education systems. Moreover, this research's subject is everything related to the aims and methods of tarekat-based education in optimizing Islamic da'wah activities.

This study uses a qualitative approach to descriptive-analytic methods. It is hoped that through this approach and method, researchers can describe the da'wah model of the tarekat at Islamic education institutions Suryalaya. The descriptive-analytic method emphasizes the 
effort to obtain information about the status or symptoms that describe the phenomenon, explain the relationship and draw the meaning of a problem that occurs (Sukmadinata, 2007: 72). In other words, this method is seen as describing the research phenomenon naturally.

This research location is located at the Islamic education institution MTs and $M A$ Serba Bakti Pesantren Suryalaya Tasikmalaya. The researcher made observations on various activities or events that reflect the da'wah model of the tarekat through Islamic educational institutions. Data collection techniques are carried out through field observations at the research location, interviews with several Kyai, teachers and students at these educational institutions and literature study by tracing related research from primary sources, including books, journals and other scientific articles. Data analysis was carried out through the phenomena of phenomenological reduction (sorting out the researchers' assumptions with phenomena data), eidetic reduction (focused categorization and data filtering) and transcendental reduction (conceptualization in the form of concluding).

\section{RESULTS AND DISCUSSIONS}

\section{Cageur-Bageur and Serba Bakti as the Purpose of Tarekat Da'wah}

In general, the purpose of Islamic education is to form a perfect human being (insan kami). This goal rests on human characteristics and qualities from an Islamic perspective. As the main guideline for human life, the AlQuran explains Islamic education's orientation in shaping human qualities that have dimensions of faith, Islam and Ihsan. From the point of view of da'wah, the purpose of Islamic education is related to efforts to internalize, diffuse, transmit and transform messages of goodness contained in the AlQuran and al-hadith to achieve the good of the world and the hereafter. In other words, the goal of Islamic education is oriented towards implementing amar maruf nahi munkar to achieve al-khoir. Both the orientation of Islamic education and da'wah are carried out in the form of qawl and charity (Kusnawan et al., 2009: 16).

Based on observations, the educational objectives of Madrasah Tsanawiyah and Madrasah Aliyah Serba Bakti Pondok Pesantren Suryalaya can be seen from the vision and mission of the institution. This refers to the Strategic Plan Document of $M T s-M A$ Serba Bakti Pesantren Suryalaya in 2012. Where the vision of this educational institution is to produce students, who are realized as "mature" Muslim who have faith, knowledge, 
achievement, service and noble character (cageur bageur physically and mentally). This vision is strengthened by seven main competencies, namely: first, graduates have a solid foundation of faith, a strong foundation of devotion, a steady lifestyle $(T A N B I H)$ and a soft heart and have Islamic social ethics (akhlakul karimah) in an effort to create Indonesian people who are cageur bageur inner and outer. Second, graduates have the ability to read, write, interpret, conclude and understand al-Quran / al-hadith and try to practice them in everyday life (in an effort to create a quranic generation).

Third, graduates have smart brains, high IQ, EQ, SQ and passionate learning and high achievement. They master various modern science and technology to provide their service to their family, society, and country. Fourth, graduates have a Muslim culture and work ethic who strive with all their might, are full of sincerity and belief in realizing the ultimate goal of life in the hereafter without the goal of living in a prosperous world. Fifth, graduates have brilliant absorption, are active, initiative, innovative, resilient, and adept at dealing with problems to become exemplary students at school, favorite children at home, and proud citizens in the community.

Sixth, graduates have great fighting power to become Muslim preachers who are persistent in upholding Allah's religion (especially the TQN syiar) to become mouthpieces and become examples of developing patterns of da'wah bil hal (da'wah with commendable deeds in many ways). Seventh, graduates have high discipline, great responsibility, a strong sense of belonging, and a solid concern and reliable and trusted in various activities to strive for future-oriented progress so that they can gain existence.

The Serba Bakti educational orientation emphasizes the "noble character" aspect. This orientation focuses on the Tanbib-TQN Suryalaya model, namely the "cageur bageur physically and spiritually." This model is translated into the policy of the core source material for character education with the characteristics (1) the characteristics of Kaffah Islam; (2) the characteristics of Pancasila as the State Philosophy; and (3) tanbih characteristics and pearl strands. These three characteristics of character education are the main reference in the process of planting, fostering, developing, and strengthening the competence of education graduates at MTs-MA Serba Bakti Pesantren Suryalaya Tasikmalaya. Where these three references are based on the teachings of tanbib-TQN and their actualization in the context of nationality and statehood.

In general, the educational objectives of pesantren Suryalaya refer to 
the Tanbih-TQN manuscript. They are divided into two main concepts, namely cageur-bageur as the basic concept of tarekat education and all devotion as a way of service. Meanwhile, TQN drikir is positioned as the main method in the process of tarkiyat an-nafs education to do taqarrub, mardhatillah, mahabbah and makrifat. Further, the phrase cageur-bageur is written at the end, namely:

Ku lantaran kitu sakabeh murid-murid kudu arapik tilik jeung pamilih, dina nyiar jalan kahadean labir bathin dunya akbirat sangkan negunah nyawa betah jasad ulah jadi kebengkahan anu disuprih "cageur bageur".

Therefore, all students should act carefully in all the paths taken, for the good of the inner world, the world, and the hereafter, so that the heart is at peace, the body is comfortable, never quarrels, no other purpose "mind and body are healthy (cageur bageur)."

The concept of cageur bageur is developed by a number of the following ethical provisions:

Inget sakabeh murid-murid, ulah kabaud ku pangwujuk napsu, kagendam ku panggoda syetan, sina awas kana jalan anu matak mangparkeun kana parentah agama jeung nagara sina telik kana diri bisi katarik ku iblis anu nyelipkeun dina bathin urang sarerea.

Anggurmah buktikrun kahadean sina medal tina kasucian:

Kabiji, ka salubureun ulab nanduk boh salubureun barkatna atawa darajatna, boh dina kabogana estu kudu luyu akur jeung batur-batur.

Kadua, ka sasama tegesna ka papantaran urang dina sagala-galana ulah rek pasea, sabalikna kudu rendah babarengan dina enggoning ngalakukeun parentah agama jeung nagara, ulah jadi pacongragan pacengkadan, bisi kaasup kana panandika 'adzabun alim, anu hartina jadi pilara salawasna, ti dunya nepi ka akberat (badan payah ati susab).

Katilu, ka sabandapeun ulab baying ngabina atawa nyieun deleka culika, henteu daek ngajenan, sabalikna kudu heman, kalawan keridloan malar senang rasana gumbira atina, ulah sina ngarasa reuwas jeung giras, rasa kapapas mamaras, anggur ditungtun dituyun ku nasehat anu lemah lembut, nu matak. nimbulkeun nurut, bisa napak dina jalan kabadean.

Kaopat, kanu pakir jeung miskin kudu welas asib someah, tur budi beresih, serta daek mere maweh, nyatakeun hate urang sareh. Geura rasakeun awak. urang sorangan kacida ngerikna ati ari dina kakurangan. Anu matak ulah rek. kajongjonan ngeunah dewek henteu lian, da pakir miskin the lain kahayangna 
sorangan, estu kadaring pangeran.

First, towards people who are higher than us, in terms of dignity or rank, or excess property, should live in harmony and respect for each other.

Second, to our fellow human beings, let there be no strife. Let us be humble, cooperate in carrying out the orders of religion and the state, let there be no strife and contention. If we did not do that, then we are part of His word " adzabun alim ", which means sorrow forever from this world to the hereafter (the body is hard-hearted).

Third, those who below us do not humiliate them or do indecent things and be arrogant. Instead, be compassionate with awareness, so that they feel happy so that they do not feel afraid and do not want to be near us because their heart is broken. They should be guided with gentle advice that will give them realization in the path of goodness.

Fourth, to the poor, must be loving, kind and generous, light-handed, as a reflection of the heart's consciousness. Try to feel ourselves personally; how painful it is to be in a state of deprivation (like them). Therefore, do not be preoccupied with personal pleasures alone, then indifferent (to them), because the poverty they experience, not merely their own will, in it there is the nature of God.

Moreover, Madrasah Serba Bakti education's basic concept refers to the purpose of Tarekat Qadiriyah and Naqsabandiyah Pondok Pesantren Suryalaya. In the description of the principles of tarekat (1960), KH. A Shohibulwafa Tajul' Arifin, presented the three basic principles of tarekat development, namely (1) taqarrub, (2) towards mardhatillah, and (3) achieving mercy and enlightenment to Allah SWT. Meanwhile, in the tanbih manuscript written by Shaykh Abdullah Mubarok bin Nur Muhammad (February 13, 1956), several life guidelines were written. There is some advice given to tanbih, first, not to do anything contrary to religion or the country's rules. This asserts that the obligation to obey religion is related to the obligation to obey the state. In this regard, it is revealed through the tanbih that "ulab kabaud ku pangwujuk napsu, kegendam ku panggoda syetan, sina awas kana jalan anu matak mangharkeun kana parentah agama jeung nagara, sina telik kana diri bisa katarik ku iblis anu nyelipkeun dina bathin urang sarerea" (do not be distracted by the indulgence of lust, enslaved by the temptations of 
Satan, beware of the path that is cast following the commandments of religion and the country, beware of yourself can be attracted by the devil who lurks in everyone's mind).

Second, proving oneself through goodness born of self-purity through elevated ethics: respect for the highest degree, cooperation and harmony with one another. Third, guide the lowly and empathize with the poor. Fourth, specifically for the ethics of others of different religions, is mentioned a special attitude, that: "ari sebagi agama, agama, saagama-agamana, nurutkeun surat al-Kafirun ayat 6: agama anjeun keur anjeun, agama kuring keur kuring. Surabna ulah jadi papaesan, "Kudu akur jeung batur-batur tapi ulab campur baur" (as a religion, according to Surat al-Kafirun verse 6: your religion is for you, my religion is for me. His message is not to say, "Have to get along with others but do not mingled).

The four ethics above's main point is "akur jeung batur-batur ulab aya kuciwana" (getting along well with others, do not feel disappointed). Humans can only carry out these four ethics described as "manusia anu pinuh ku karumasaan" (humans who feel self-conscious). The principle that underlies the four ethics of life is the proverb "dawuh sepub baheula: "sina logor dina liang jarum, ulab sereg di buana" (let it loose in the needle hole, lest it be narrow on the continent).. The principle of sina logor dina liang jarum means (a) to always be optimistic and not to feel pressured by the lack of difficulties; (b) not being bothered by the existence of different people; and (c) continue to do good in the middle of an unsupportive situation. While the principle of ulah sereg di buana can be interpreted as (a) sharing the space of life for all humans; (b) always looking for new possibilities in organizing life; (c) graceful attitude in living together.

Other guidelines for living ethics as a missionary goal for the tarekat based on Islamic education in Suryalaya are found in the quotes written by KH. Shahibulwafa Tajul 'Arifin or Abah Anom. The quotes are:

Ulab ngewa ka ulama sajaman

Ulah nyalabkeun kana pangajaran batur

Ulah mariksa murid batur

Ulah medal sila upama kapanah

Kudu asih ka jalma nu mikangewa maneh

The quotes above teach an attitude of not hating (ngewa) towards other teachings and/or mursyid; does not blame and/or correct the teachings of other tarekat, and does not correct (blame or correct) students 
of other tarekat; even if there is a debate with another tarekat, it is forbidden to act emotionally (medal sila) and still show kindness to the opponent who shows hatred (mikangewa) towards the teachings of TQN.

The aims, ethics, and basic principles of da'wah ethics based on tarekat education above boil down to efforts to manifest attitudes and actions based on goodness or morals. Akhlakul karimah is considered very important, so it must be constantly trained, accustomed to, nurtured, and practiced. Actions are considered to be a source of happiness and unhappiness. This is confirmed by the expression stated karana nu matak tugeunah terhadap badan urang masing-masing eta the tapak amal perbuatanana (because that casts a shadow over our respective bodies; it is the charity site of our deeds). In this expression, Abah Anom realizes that the root of all the tribulations of life is an act that does not bring good to others.

The implementation of the basic concept of tarekat education as the basis for Islamic da'wah activities at TQN is applied not only to TQN students but also to the values, spirit, and soul that animate various Islamic educational institutions under the auspices of TQN. This can be seen from the basic concepts of education, objectives, programs, processes, and educational evaluation implementation at MTs and MA Serba Bakti Suryalaya. In fact, applying these concepts is evident from the use of names, logo identities, vision and mission formulations, and profiles of graduates of these educational institutions. This is because the estuary of acts of kindness, which is meant as part of Islamic preaching in the TQN paradigm, is referred to as "Serba Bakti" meaning that tanbih guidelines and quotes frame all the actions of pangersa abah students. The multiplicity of devotion makes all the abah students' activities in various spheres of life, including in educational institutions, to continue to correct their actions so that the goodness is done as a form of devotion to Allah SWT and the Prophet Saw.

The tarekat da'wah's aim through Islamic education institutions at MTs-MA Serba Bakti Pesantren Suryalaya is oriented towards efforts to improve and process self-correction. In this self-correction, it is emphasized in the tanbih text to carry out the process of examining one's own actions and intentions for actions and always orienting the choice of action for the good of the world and the hereafter. This affirmation is contained in the sentence:

Sakabeh murid-murid kudu arapik tilik jeung pamilih, dina nyiar jalan kahadean labir bathin, dunya akherat, sangkan ngeunah nyawa betah jasad, 
ulah jadi kebengkahan anu disuprih "cageur bageur".

"All students should act carefully and choose the best in all the paths taken, use the good in the inner world, the world and the hereafter so that the heart is calm, and the body is comfortable, never quarrel arises, no other purpose except mind and body are healthy".

The expression tilik jeung pamilih (act carefully) shows the need to get used to self-correction and actions as a method or path of goodness (da'wah). While the expression ngeunah nyawa betah jasad (the heart is calm and the body is comfortable) atau cageur bageur shows the tarekat da'wah's purpose in forming harmony of inner and outer goodness to achieve happiness in the world and the hereafter. Both these goals and methods become a frame of reference that underlies every behavior, attitude, selfidentity, and action that is oriented towards the manifestation of goodness both in the TQN environment, the general public, teachings, and/or adherents of teachings with different views or with the object of preaching even from non-Muslims. The tanbih manuscripts and quotes in shaping human beings who are all cageur bageur serba bakti ecome the souls that underlie every practice and role model at $M T s-M A$ Serba Bakti and all da'wah, education and social activities in pesantren Suryalaya, Tasikmalaya.

Tarekat da'wah can be said to be a transformative da'wah effort oriented towards realizing an Islamic society. Transformative da'wah is a da'wah model, which does not only rely on verbal (conventional) preaching to provide religious materials to the community, which positions preachers as a spreader of religious messages but also internalizes religious messages into the real life of society by doing direct community assistance (Rifqi Hakim, 2018: 20). In this case, the mursyid's existence has a strategic role as a preacher who transmits religious messages and directs, accompanies, and becomes a role model in tarekat practice. The task of the mursyid is to help cleanse the hearts of students from the rust of lust and the nature of the invitation and inclination of the heart, the light of the beauty of the unity and the greatness of the eternity that is reflected in the heart so that their eyes can be enchanted by looking at them. So that divine love resides in their sincere hearts (Qomariah, 2019: 186).

Tarekat is a methodology performed by a Sufi in achieving the three goals of Sufism, namely tazkiyat al-nafs, purifying the soul from various liver diseases; taqarrub ila Allah, getting closer to Allah as close as possible; and 
budhûr al-qalb ma'allâh, feeling the presence of Allah in the heart (Usman, 2018: 199). Efforts to do this taqarrub is made through self-training and purification of the heart to obtain mardhatillah, so that it becomes a person who loves and enlightens Allah (Pujiastuti, 2016: 71). In the context of da'wah, the process of calling to al-khair will lead man to be a person who adorns himself with the values of akhlakul karimah, so that all the good deeds practiced will lead man to become a preacher who do amar maruf nahi munkar.

The tarekat da'wah has an acculturative-evolutive pattern, where the medium of the tarekat da'wah is the culture itself. Tarekat da'wah is always required to be creative, innovative, and adaptive to the development trends and its people's socio-cultural conditions (Riyadi, 2014: 379). Tarekat da'wah must modify and transform local culture into a cultural form that is packaged and inspired with Islamic values. The transformative da'wah of the tarekat is carried out by carrying out the social roles and functions of the tarekat in terms of personality, figure, community, and even the institutionality of the tarekat itself. In other words, this transformation is carried out by both murysid and/or shaykhs (main teachers), talqin guardians, students, tarekat teachings, ikhwan/congregation to the tarekat organization itself (pesantren, madrasah, schools, etc.).

In principle, tarekat da'wah activities are carried out, referring to the purpose of training and self-formation, which is carried out through a selfcleansing process to achieve peace of mind. The calmness in question is obtained at the individual level and the inter-individual and communal levels. This is what is meant by the term cageur bageur and all-around service in the context of the TQN Suryalaya tarekat da'wah objectives. The spiritual accompaniment process carried out by the murysid to cleanse the soul through the dhikr method is to achieve happiness in the world and the hereafter, sangkan ngeunah nyawa betah jasad.

\section{Dhikr as a Method of Da'wah Tazkiyat An-Nafs}

In principle, dhikr is the main method in the tarekat-based education process formulated at the MTs-MA Serba Bakti Suryalaya educational institution. This refers to the results of observations and interviews that state that most of the tarekat education methods practiced in the internalization of the Serba Bakti Foundation's da'wah objectives are deeds carried out by TQN practitioner's dhikr and imitating Abah Anom.

The concept of dhikr in TQN can be referred to from the Tanbih and 
Uqudul Juman books. In the final section, after explaining ethics, the following points are stated:

Ulab kabaud ku pangwujuk napsu, kagendam ku panggoda syetan, sina awas kana jalan anu matak mengparkeun kana parentah agama jeung nagara sina telik kana diri bisi katarik ku iblis nu nyelipkeun dina bathin urang sarerea. "...Sakabeh murid-murid kudu arapik tilik jeung pamilih dina nyiar jalan kahadean labir batin, dunia akhirat, sangkan ngeunah nyawa betah jasad, ulah jadi kabengkahan ..."

"Teu aya lian pagawean urang sarerea Thariqah Qadiriyah Naqsabandiyah amalkeun kalawan enya-enya keur ngahontal sagala kahadean dlobir bathin, keur nyingkahan sagala kagorengan dlohir bathin, anu ngeunaan ka jasad utama nyawa, anu dirungrung ku pangwujuk napsu, digoda ku dayana setan.

The three quotations above do not explicitly state about dhikr or method cageur baguer, except in sentence (1) "...sakabeb murid-murid kudu arapik tilik jeung pamilib dina nyiar jalan kahadean..." (all students should be able to look and carefully search for a way of kindness); dan (2) "Teu aya lian pagawean urang sarerea Thariqah Qadiriyyah Naqsabandiyyah amalkeun kalawan enya-enya" (there is no other work for us except practice Thariqah Qadiriyyah Naqsabandiyyah with earnestness). The second quote shows the belief system of man's basic condition, which is based on the tendency of lust strengthened by Satan's temptations. It is stated in the second quote that Ulah kabaud ku pangwujuk napsu, kagendam ku panggoda syetan, sina awas kana jalan anu matak mengarkeun kana parentah agama jeung nagara sina telik kana diri bisi katarik ku iblis nu nyelipkeun dina bathin urang sarerea (do not be distracted by the lure of lust, overwhelmed by Satan's temptation, beware of the path that is parked in the precepts of religion and the country beware of yourself in case you are attracted to the devil who slips in everyone's mind). hese two sentences are in pairs if the following formula is arranged: Ulah kabaud ku pangwujuk napsu $\longrightarrow$ sina awas kana jalan anu matak mengparkeun kana parentah agama jeung nagara

- [Ulab] kagendam ku panggoda syetan $\longrightarrow$ sina telik kana diri bisi katarik ku iblis nu nyelipkeun dina bathin urang sarerea.

The basic condition of a human being in this description is to have a passion that can lead to indifference or anu matak mengparkeun kana parentah agama jeung nagara. This sentence is related to the concept of al-nafs al-mar'ah bi al-syu'i. The second basic condition, the human self, can be affected by 
Satan and the devil who seduces in the human heart (mind). Nafs (amarab bi al-syu'i) and gendam penggoda iblis are not real. They both work on the human heart, on the thinking program that results in action-type decisions. This requires a careful observation method:

"...Sakabeh murid-murid kudu arapik tilik jeung pamilib dina nyiar jalan kahadean labir batin, dunia akhirat, sangkan ngeunah nyawa betah jasad, ulah jadi kabengkahan ..."

The above quote not only implies the need to observe one's own symptoms (arapik tilik), but is added with arapik pamilib or making decisions (actions). The word tilik in Sundanese means "to be careful" (as a noun), while as a verb, it can mean nenjo or nilik, which means (1) to see seriously; (2) observe, inspect and control; (3) looking from a certain perspective. Tilik also means careful vision, especially seeing with the mind's eye. While pamilib means the act of choice after considering, here the word pamilib is related to the word tilik; or make choices (pamilib) based on observations (acts of observation with the mind's eye). Thus, the work of choice is not done by the mind, but by the 'mind' (which in turn produces cageur). The work of tilik-pamilith can be called as pagawean urang sarerea Thariqah Qadiriyyah Naqsabandiyyah.

Tazkiyat al-Nafs is a process of purifying body and soul to improve humanity's quality in attaining the noble human degree, insan kamil. There are three forces in the taqkiyat al-nafs process: takhalli, tahalli, and tajalli. These three can be loosely translated as 'purification of energy, the transformation of energy, and generation of potential.' In general, the activity of tazkiyat al-nafs leads to two tendencies, namely (1) cleansing the soul from reprehensible traits, removing all the heart illness (takhalli); and (2) adorn the soul with a commendable character (taballi). Regarding this, Abah Anom wrote:

“... cleanses his heart of humility and fills it with all virtues. Moreover, at that time, his heart must believe in the holy light of Allah, so that the person obey Allah rather than following his desires and from everything other than Allah, because that Allah ta'ala, the Great and Mighty, is an offering that is sought, favored and loved." (KH. Shahibulwafa Tajul 'Arifin, TQN Suryalaya).

This purification of the heart is done by the method of dhikr:

"... Disappear from his heart with the power of dhikr of forgetful 
darkness and disobedience, gradually. Lust is released from the moment of the nature of humility and filled with all the qualities of virtue. Then it can reach Anwarul Hal, Nur, who is full of eternal truth in God. Then he calms down, prostrated to his Lord, and remained with his Lord. He loves God, and God loves him” (KH. Shahibulwafa Tajul 'Arifin, TQN Suryalaya).

"Verbal dhikr will convey and help the perpetrator to dhikr of the heart. Azy-Syazili stated that mustard seeds from the deeds of the heart, as big as a mountain from the deeds of the body... Dhikralthough it seems not to affect- can keep the perpetrator from feeling worried. When he [someone] wants to work budur, let him sit together with his shaykh and his brothers who have obtained uns (inner peace) in taking the path to Allah" (KH. Shahibulwafa Tajul "Arifin, TQN Suryalaya).

In TQN it is believed that the improvement of human behavior starts from the purification of the soul (from negative things) through dhikr activities to Allah SWT. Neglect and bad behavior are believed to be caused by invisible heart illness but cause the emergence of nafs ammarah bissui (lust that leads to a tendency to evil). Dzikir, which is meant in TQN is to remain present in the heart with Allah Ta'ala. Thus, the prayers contain dhikr, zakat, hajj, learning activities, reading, fatwa, and doing good deeds maruf nabi munkar and as a manifestation of dhikr. The dhikr method is gradually introduced from dhikr with the tongue and then increases regularly with the heart's dhikr. After becoming a habit, it increases again into dhikr sirri.

Dhikr as the tazkiyat al-nafs method becomes the epicenter of the tarekat da'wah method in various activity spheres. Dhikr, either verbally, heart, and sirri is oriented towards cleansing the soul from all kinds of darkness, leading to the nafs ammarah bissui'. Dhikr is an attempt to tilik.jeung pamilib in action. Dhikr is done to cleanse the lust that tends to be ghoflah or negligent from goodness. In this case, dhikr cleanses the heart so that actions are good. Practicing TQN as a whole is a way of cleansing the heart that will result in acts of kindness.

Dhikr is the main practice of the teachings of this tarekat. Dhikr is an effort to remember Allah SWT by reciting the sentence laa ilaha illallah. Dhikr strengthens each individual to continue to make improvements and corrections to all his / her actions. The practice of dhikr becomes a way to 
get closer to Allah SWT (Usman, 2017: 183). The teachings of the tarekat seek to provide spiritual guidance so that humans always fill themselves with morals so that they get peace of mind. This process of spiritual strengthening and soul reform is carried out through the practice of dhikr. Where dhikr is the commandment of Allah SWT, which is contained in the al-Quran, this dhikr method is one way to get peace of mind (al-Nafs Muthmainnah) (Rifqi Hakim, 2018: 4).

The whole habituation of this dhikr practice is carried out to strengthen one's character as a human being oriented towards the achievement of cageur bageur serba bakti. Where humans continue to make corrections carefully so that all their actions make them feel at home. The dhikr concept as a tazkiyat al-nafs da'wah tarekat is also implemented through the Serba Bakti Foundation educational institution. Every school member, both teachers, and students are accustomed to practicing dhikr to habituate the practice that leads to good actions. This can be seen from the formulation of the vision and mission, the profile of graduates, educational programs, educational processes, curricular and co-curricular activities, to various school activities that reflect the basic concepts of TQN education, tanbih, and quotation descriptions as practiced by Pangersa Abah Anom.

As for tanbih and quotation can be described in the chart below: 


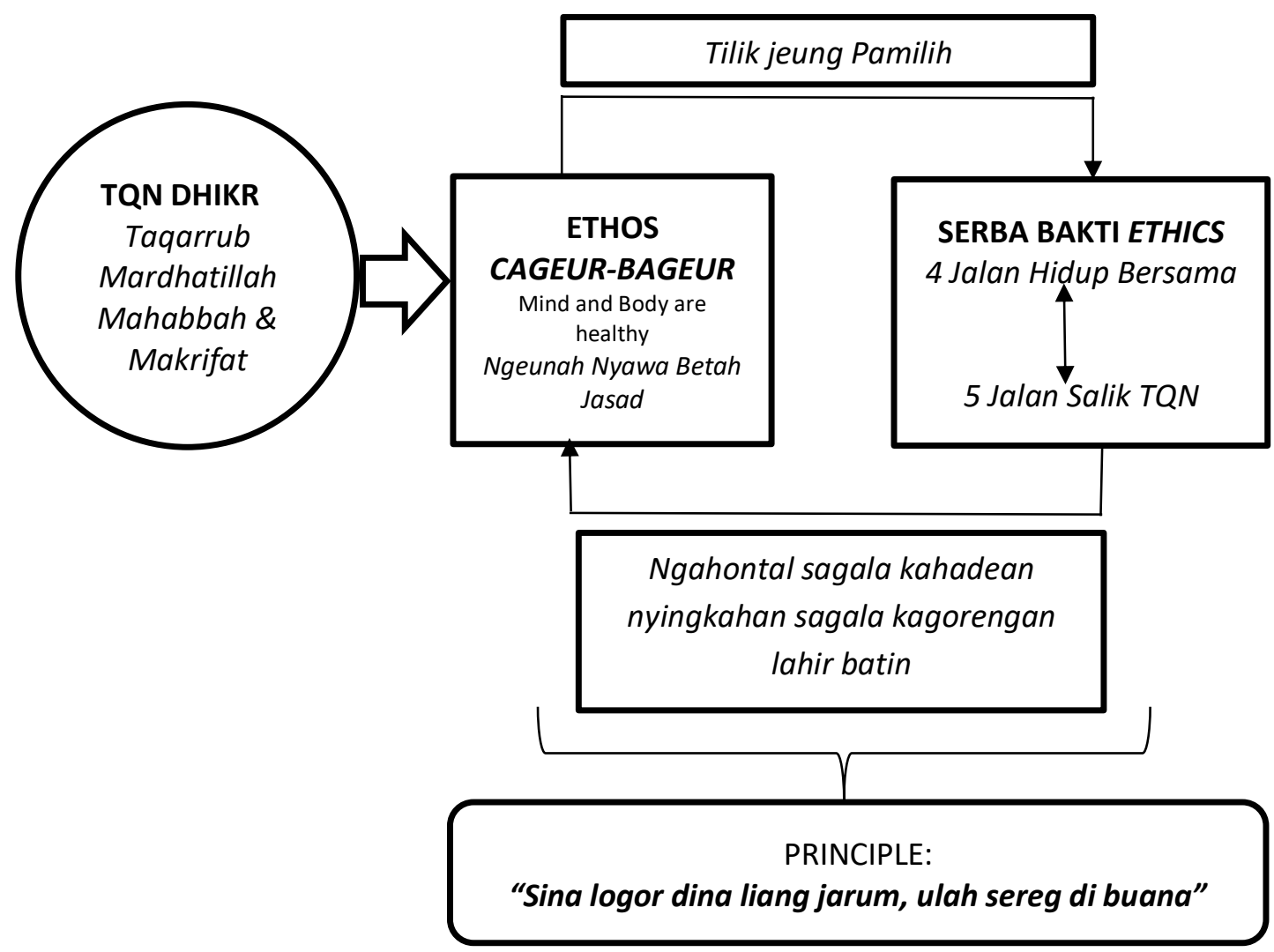

Source: Researcher's Observation

Chart 1. Basic Concepts of TQN Suryalaya Education

Chart 1 above is a schematic of the basic concepts of TQN education, which contains the objectives, principles, ethics, and educational methods as the basis for the tarekat Da'wah activities of the Suryalaya. From the above scheme, it is found that the center of TQN's personality is Cageur Bageur in order to produce Serba-Bakti actions. The basic concept scheme above revives the various tarekat da'wah activities of the Suryalaya, including reviving Islamic educational institutions under pesantren Suryalaya assistances such as the Serba Bakti Foundation, pesantren INABAH, Higher Education, and other educational centers.

The word cageur bageur is defined as the main mind, the perfect body. The combined cageur bageur can formulate a specific meaning. First, the 
condition of cageur, which is when the mind has attained primacy, produces bageur, namely ethical behavior according to common norms. Second, the conditions of cageur and bageur in many humans are not connected. What is in the mind is not a source of ethical behavior in a person. TQN in tanbih shows an orientation that harmonizes these two aspects, such as in the sentence sangkan ngeunah nyawa betah jasad, ulah jadi kabengkahan. The word ulah jadi kabengkahan indicates a necessity to harmonize the conditions between cageur and bageur.

When associated with cageur bageur, the concept of devotion is cageur as an expression of bageur or ethical goodness based on virtue. Devotion here can be summarized as the act of kindness of the primary mind. This can be seen in the four ethics of living together and the five ethics of TQN. In the four ethics of living together, TQN students are emphasized to keep devotion to people of a higher, lower, and equal rank. The services that are meant are: (1) ulah hayang ngabina atawa nyieun deleka culika, (2) daek ngajenan, (3) kudu heman, (4) senang rasana gumbira atina, (5) ulab ngarasa reuwas jeung giras, (6) memberi nasehat anu lemah lembut nu matak nimbulkeun nurut bisa napak dina jalan kahadean, (7) kudu welas asih someah, (8) tur budi beresih sarta daek mere maweh, dan (9) empathy (geura rasakeun awak urang sorangan kacida ngerikna ati ari dina kakurangan).

Meanwhile, towards fellow tarekat adherents from other tarekat, the word service is formulated as attitudes (1) ulah ngewa ka ulama sajaman; (2) ulah nyalabkeun kana pangajaran batur; (3) ulah mariksa murid batur; (4) ulah medal sila upama kapanah; and (5) kudu asib ka jalma nu mikangewa maneh. This TQN salik ethic shows the importance of being tolerant of different understandings. This is interpreted as a path of salik in harmonizing actions so that the method of tilik jeung pamilih, self-correcting, self-intention, and self-action become the epicenter in practicing TQN principles and ethics so that they can achieve the goals as set out in the tambih and quotes, and are practiced by Abah Anom.

The principles and ethics in the TQN teachings above can be seen as a message of Islamic moderation that teaches the principles of balance, justice, and harmony in various human activity spheres. The four ways of living together and the five ethics of the path of TQN show that there is a need to create harmony and connection with one another. This harmony is established in the form of carrying out obligations towards religion and the state, respect and appreciation for people of a higher rank, respect for people who have the same degree, empathy for those below, respect for 
the environment, and maintenance of theological and spiritual aspects (Somantri \& Dahwadin, 2019: 61).

Da'wah is an effort to convey sharia, while tarekat is the embodiment of da'wah material used as a reference in the tarekat's activities itself (Qomariah, 2019: 190). The implementation of this tarekat da'wah's aims and methods is translated into the domain of Islamic education institutions under the auspices of pesantren Suryalaya. Both in terms of programs, processes, and efforts to measure and evaluate the achievement of these educational goals. Tarekat da'wah, which is carried out through Islamic education institutions, is carried out through tarekat-based education. A tarekat-based education program inculcates tarekat values through teaching, modeling, giving motivation, and implementing rules.

Tarekat-based education programs are developed through two domain backgrounds, namely a macro background and a micro background. The macro background is a foundation that covers the entire context of planning and implementation of value/personality development that involves all educational stakeholders at the Serba Bakti Foundation. Meanwhile, the micro background can be seen in the teaching program, which includes delivering knowledge and skills. It is hoped that both the macro and micro settings will have an effect or result. This influence or result comes from habituation, so it becomes a character in every educational process carried out (Hasanah, 2013: 136).

On a macro background, the implementation of this tarekat da'wah is carried out in the form of basic concepts, objectives, and methods to achieve a cageur bageur inner and outer personality. This is described in the vision, mission, and competency profile of the Serba Bakti Foundation's graduates. Meanwhile, this implementation is translated into school or madrasah culture, teaching and learning process, co-curricular activities, and daily practices that students are accustomed to in the micro setting. However, at $M T s-M A$ Serba Bakti, both on a macro and micro background, the dominant values, beliefs, principles, and ethics stem from tanbih, quotations, and the figure of $A b a b$ Anom. The core source of learning is oriented towards cultivating character education that harmonizes religious education and civic education, where the characteristics that are used as references are (1) the characteristics of Kaffah Islam, (2) the characteristics of Pancasila as the State Philosophy, and (3) the characteristics of Tanbih and quotations.

The tarekat da'wah carried out by pesantren Suryalaya through Islamic 
education institutions such as $M T s-M A$ Serba Bakti shows the strong commitment and consistency of pesantren Suryalaya in transmitting messages of goodness (amar maruf nabi munkar) to form a personality that has inner and outer harmony. Da'wah, as an effort to call for goodness in the way of Allah SW'T (sabili rabbika) aims to create an ecosystem of people who have a moral personality. This personality is produced through training, self-habituation, and practice to become characteristic and manifests itself in the sphere of communal life. At this point, da'wah activities must be diverted into various spheres of human activity in the context of religion, culture, social, education, economy, and even politics.

Da'wah aims to instill the value of faith and devotion to form a person who has acts of kindness so that he can achieve happiness in the world and the hereafter. This goal is in line with the self-conscious projection of human beings depicted in the tanbih and quotes of pesantren Suryalaya. The teachings of TQN are oriented to the achievement of a life that is cageur bageur ngeunah nyawa betah jasad. This is interpreted as a prototype of a human being who constantly trains himself, cleanses his heart with dhikr, is empathetic, tolerant, and always respects and avoids all forms of neglect. Thus, the estuary of all these actions develops into happiness both in this world and in the hereafter.

\section{CONCLUSION}

Tarekat Da'wah carried out by pesantren Suryalaya through Islamic educational institutions such as $M T s-M A$ Serba Bakti is based on the teachings of TQN, the Tanbih script, the quotations, and the exemplary figure of $A b a b$ Anom. Its implementation can be seen both on a macro background and a micro background. The macro background collects various applications that involve all educational stakeholders at the Serba Bakti Foundation. In contrast, it deals with the inculcation of values and personality in students on the micro background. In the macro background, implementation is carried out, starting from the formulation of institutional graduates' vision, mission, and competency profile. Moreover, in the micro background, it can be seen from the habituation of school culture, teaching and learning process, co-curricular activities to students' daily activities.

Basically, the implementation of tarekat da'wah at the Suryalaya Islamic educational institution is directed at character education that harmonizes religious education and civic education. The expected 
characteristics are (1) the characteristics of Kaffah Islam, (2) the characteristics of Pancasila as the country's philosophy, and (3) the characteristics of Tanbih and the quotation. This refers to the main purpose of the tarekat da'wah, namely to form a human with a moral character, a human being who is full of devotion. Namely, humans who practice the basic concepts, principles, and ethics according to the teachings of TQN, tanbih, quote, and Abah Anom's example in the process of interaction (muamalah) in various spheres of life.

Moreover, this tarekat da'wah's purpose is reflected in various daily activities that are trained through the habituation of dhikr. Dhikr is seen as a method of tarkiyat al-nafs that can cleanse the heart and soothe the human soul. Dhikr is done in stages, from getting used to verbal dhikr, moving on to heart dhikr, and doing sirri dhikr consistently. This means that all human actions and deeds must be in the context of dhikr to Allah SWT. Dhikr, as the method of tarkiyat al-nafs becomes the epicenter in the implementation of taqarrub ilallah, brings mardhatillah and mahabbah to achieve makrifatullah. In this case, dhikr is seen as a method of proselytizing the tarekat, which is practically implemented in various spheres of da'wah activities at pesantren Suryalaya. This includes the daily application in $M T s-M A$ Serba Bakti educational institutions. This method is applied as part of the value system that dominates students' activities so that it is expected to influence their actions. In turn, it develops into human beings who are cageur bageur physically and mentally as the vision of educational institutions at the Serba Bakti Foundation.

The actualization of tarekat da'wah through Islamic educational institutions has implications for the efforts, commitment, and consistency of TQN teachings in narrating tilik pamilib at the level of personal and social life. This action is based on the ethical principles of cageur bageur and serba bakti both in terms of the harmonious way of life and the path of salik that intersects with the teachings of others tarekat. The da'wah of the tarekat in Islamic educational institutions shows the harmony between the purpose of da'wah and the output of Islamic education, which seeks to form a perfect human being (insan kamil), so that this human figure is those who tilik pamilib dina nyiar jalan kahadean labir batin, dunia akhirat, sangkan ngeunah nyawa betah jasad, ulab jadi kabengkahan. These figures are those who consistently practice the ethical principle that as a human being ulah kabaud ku pangwujuk napsu, kagendam ku panggoda syetan, sina awas kana jalan anu matak mengparkeun kana parentah agama jeung nagara sina telik kana diri bisi katarik ku 
iblis nu nyelipkeun dina bathin urang sarerea. In the end, the estuary of all these activities is commitment and consistency to teu aya lian pagawean urang sarerea Thariqah Qadiriyah Naqsabandiyah amalkeun kalawan enya-enya keur ngahontal sagala kahadean dlobir bathin.

\section{REFERENCES}

Arifin, S. T. (1960). Miftabus Shudur. TQN Suryalaya.

Aripudin, A. (2011). Tarekat dan Perkembangan Dakwah di Indonesia, Ilmu Dakwah: Academic Joumal for Homiletic Studies, 5(17), 323-346. DOI :10.15575/idajhs.v5i17.369.

Asror, A. K., Kusnawan, A., \& Fajar, D. A. (2017). Rehabilitasi Korban Penyalahgunaan Narkoba melalui Terapi Religius di Yayasan Serba Bakti Pondok Pesantren Suryalaya Inabah XIV Garut, Irsyad: Jurnal Bimbingan, Penyuluban, Konseling, dan Psikoterapi Islam, 5(1), 21-38. https://jurnal.fdk.uinsgd.ac.id/index.php/irsyad/article/view/881.

Azra, A. (1999). Renaisans Islam Asia Tenggara Sejarab Wacana \& Kekuasaan. Bandung: PT Remaja Rosdakarya.

Hasanah, A. (2013). Pendidikan Karakter Berperspektif Islam. Bandung: Intan Komunikas.

Hudan Alfariz, A. S., \& Taftazani, B. M. (2020). Tingkat Stress Penyalahguna NAPZA Saat Menjalani Rehabilitasi di Inabah XV Pondok Pesantren Suryalaya, Share: Social Work Journal, 10(1), 29-39. DOI: $10.24198 /$ share.v10i1.25992.

Jamaludin, O. (2018). Peran Wakil Talqin dalam Pengembangan Dakwah Tarekat, ANIDA (Aktualisasi Nuansa Imu Dakwah), 18(2), 159-180. DOI: https://doi.org/10.15575/anida.v18i2.5074.

Kusnawan, A., et.al. (2009). Dimensi Ilmu Dakwah Tinjanan Dakwah dari Aspek Ontologi, Existemologi, Aksiolohi hingga Paradigma Pengembangan Profesionalisme. Bandung: Widya Padjadjaran.

Lestari, P. (2013). Metode Terapi dan Rehabilitasi Korban NAPZA di Pondok Pesantren Suryalaya Tasikmalaya, SOCLA Jurnal Ilmu-Ilmu Sosial), 10(2), 100-107. DOI: https://doi.org/10.21831/socia.v10i2.5346.

Lutfhi, D. (2017). Talqin Zikir sebagai Metode Dakwah, Ilmu Dakwah: Academic Journal for Homiletic Studies, 10(2), 369-383. DOI: 10.15575/idajhs.v12i.2383.

Mastuhu. (1994). Dinamika Sistem Pendidikan Pesantren. Jakarta: INIS. Muhaimin. (2009). Rekonstruksi Pendidikan Islam. Jakarta: Rajawali Press. 
Tarekat Da'wah through the Islamic Educational Institutions at Pesantren Suryalaya

Mukri, S. G., Rosyadi, A. R., \& Saefuddin, D. (2015). Metode Pendidikan Islam dalam Penanggulangan Penyalahgunaan Narkoba bagi Remaja di Pondok Remaja Inabah Suryalaya Tasikmalaya, Ta'dibuna: Jurnal Pendidikan Islam, 4(1), 43-68. DOI: http://dx.doi.org/10.32832/tadibuna.v4i1.575.

Pujiastuti, T. (2016). Perkembangan Tarekat Qadiriyyah-Naqshabandiyyah di Pesantren Suryalaya, El-Afkar: Jurnal Pemikiran Keislaman dan Tafsir Hadis, $\quad$ 5(2), 71-82. DOI: http://dx.doi.org/10.29300/jpkth.v5i2.1134.

Qomariah, M. (2019). Dakwah Humanis melaui Gerakan Tarekat, Jurnal Ilmu Dakwah, 39(2), 183-196. DOI: 10.21580/jid.v39.2.4674.

Rifqi Hakim, M. R. R. (2018). Strategi Dakwah pada Masyarakat Tarekat (Studi Kasus pada Kegiatan Tarekat Qodiriyah Wa Naqsyabandiyah di Ponpes Futuhiyyah Mranggen Demak), Lentera: Jumal Ilmu Dakwah dan Komunikasi, 2(1), 1-25. DOI: 10.21093/lentera.v1i3.1152.

Riyadi, A. (2014). Tarekat Sebagai Organisasi Tasawuf (Melacak Peran Tarekat dalam Perkembangan Dakwah Islamiyah), Attaqaddum, 6(2), 359-385. DOI: 10.21580/at.v6i2.716.

Rustandi, R. (2019). Cyberdakwah: Internet sebagai Media Baru dalam Sistem Komunikasi Dakwah Islam, Nalar: Jurnal Peradaban dan Pemikiran Islam, 3(2), 84-95. DOI: https://doi.org/10.23971/njppi.v3i2.1678.

Salahudin, A. (2013). Komunikasi Kaum Tarekat Studi tentang Pola-Pola Komunikasi dalam Kelompok Tarekat Qadiriyah Naqsyabandiyah di Pesantren Suryalaya Tasikmalaya, IJ AD (Indonesian Journal of Dialectics), 3(1), 1-14. http://jurnal.unpad.ac.id/ijad/article/view/3621/2419.

Sayyi, A. (2017). Wasiat Pendidikan Sufistik Dalam Naskah Tanbih Mursyid Tarekat Qodiriyyah Naqsyabandiyah Suryalaya (Telaah Pemikiran Guru Mursyid Tqn Suryalay), FIKROTUNA: Jurnal Pendidikan dan Manajemen Islam, 5(1), 1-22. DOI: https://doi.org/10.32806/jf.v5i1.2947.

Somantri, M. D., \& Dahwadin. (2019). The Message of Religious Moderation in Tanbih Qadiriyah Naqsyabandiyah (TQN) Pondok Pesantren Suryalaya, Teosofia: Indonesian Journal of Islamic Mysticism, 8(1), 51-68. DOI: 10.21580/tos.v8i1.4404.

Steenbrink, K. (1986). Pesantren, Madrasah, Sekolah. Jakarta: LP3ES.

Suherdiana, D. (2009). Model Dakwah Fardiyah Tarekat Qodiriyah Wa Naqsabandiyah, Ilmu Dakwah: Academic Journal for Homiletic Studies, 
4(14), 689-698. DOI :10.15575/idajhs.v4i14.417.

Sukmadinata, N. S. (2007). Metode Penelitian Pendidikan. Bandung: PT Remaja Rosdakarya.

Usman, A. (2018). Fenomena Tarekat di Zaman Now: Telaah atas Ajaran dan Amalan TQN Suryalaya, Dakwah: Jurnal Kajian Dakwah dan Kemasyarakatan, 22(2),
10.15408/dakwah.v22i2.12068.

198-216. DOI:

Usman, M. (2017). Komunikasi Spiritual Syekh Muhammad Abdul Gaos Saefulloh melalui Gerakan Dakwah Tarekat, Imu Dakwah: Academic Journal for Homiletic Studies, 11(1), 177-194. DOI: https://doi.org/10.15575/idajhs.v11i1.1529.

Yayasan Serba Bakti. (2012). Rencana Strategis (Renstra) MTs-MA Serba Bakti Pesantren Suryalaya. Yayasan Serba Bakti Pondok Pesantren Suryalaya. Zamakhsary, D. (1983). Tradisi Pesantren Studi tentang Pandangan Hidup Kyai. Jakarta: LP3ES. 